\title{
Tingkat Pendidikan dan Status Ekonomi Pemilik Hewan Kesayangan dalam Hal Pengetahuan dan Penerapan Kesejahteraan Hewan
}

\section{(EDUCATION LEVEL AND ECONOMIC STATUS OF PET OWNERS ON KNOWLEDGE AND ANIMAL WELFARE IMPLEMENTATION)}

\author{
Dwi Utari Rahmiati ${ }^{1}$, Eko Sugeng Pribadi ${ }^{2}$ \\ ${ }^{1}$ Program Sarjana Kedokteran Hewan, ${ }^{2}$ Bagian Mikrobiologi Medik, \\ Departemen Ilmu Penyakit Hewan dan Kesehatan Masyarakat Veteriner, \\ Fakultas Kedokteran Hewan, Institut Pertanian Bogor. \\ Kampus IPB Dramaga, Jl. Agatis Dramaga Bogor 16680 \\ Email : ayiq_uteri@yahoo.com.+62857 39212862 \\ eko.spribadi@yahoo.co.id.+62251-8423-313
}

\begin{abstract}
ABSTRAK
Hewan peliharaan adalah hewan yang kehidupannya untuk sebagian atau seluruhnya bergantung pada manusia untuk maksud tertentu. Memelihara hewan peliharaan (companion animal) harus memerhatikan kesejahteraan hewan. Penelitian ini bertujuan mendapatkan gambaran mengenai hubungan tingkat pendidikan dan status ekonomi pemilik hewan peliharaan dengan pengetahuan dan penerapan asas kesejahteraan hewan. Data penelitian diperoleh melalui wawancara langsung atau face to face interview bagi pengunjung di lokasi penelitian (accidental technique). Data diolah dengan uji chi square untuk menguji hubungan dua variabel. Dari hasil penelitian didapatkan hubungan yang bermakna antara status ekonomi dengan perilaku responden Jakarta Utara ( $p$ value $=0,040$ ), status ekonomi dengan sikap responden Jakarta Pusat ( $p$ value $=0,020)$, tingkat pendidikan dengan sikap responden Jakarta Selatan $(p$ value $=0,000)$. Tidak ada perbedaan nyata antara tingkat pendidikan dan status ekonomi dengan pengetahuan responden yang diamati dikeempat lokasi penelitian. Namun berdasarkan informasi dan pengamatan saat penelitian, responden Jakarta Utara dan responden Jakarta Barat dinilai mampu menunjukkan pengetahuan yang cukup tinggi tentang asas kesejahteraan hewan.
\end{abstract}

Kata-kata kunci : kesejahteraan hewan, status ekonomi, tingkat pendidikan

\begin{abstract}
Pet is an animal that lives to partially or completely dependent on humans for a particular purpose. Keep a pet as a companion animal, should pay attention to animal welfare. This study aims to gain insight about the relationship between education level and economic status of pet owners on knowledge and implementation of the animal welfare principles. The data were collecting by direct interview or a face to face interview to the animal clinic or hospital visitors on site (accidental technique). The data were calculated by statistical methods chi square to examined the relationship or the impact of the two nominal variables and measure the strengthness of the relationships between variables with each other nominal variables. Data showed a significantly correlation between the economic status of $\mathrm{n}$ North Jakarta respondents behavior ( $p$ value is 0.040 ), with the economic status of the Central Jakarta respondents' attitudes ( $p$ value is 0.020 ), level of education and attitude of South Jakarta respondents ( $p$ value is 0.000 ). There were no difference significantly between the level of education and economic status of the respondents' knowledge was observed in all study sites. However, based on current information and on site observation, North Jakarta and West Jakarta respondents were considered to be able to demonstrate more sufficient knowledge of the animal welfare principles.
\end{abstract}

Keywords : animal welfare, economic status, education level 


\section{PENDAHULUAN}

Hewan peliharaan adalah hewan yang sebagian atau seluruh kehidupannya bergantung pada manusia untuk maksud tertentu. Ternak adalah hewan peliharaan yang produknya dimanfaatkan sebagai pangan, bahan baku industri, jasa, dan/atau hasil ikutannya yang terkait dengan pertanian (Pemerintah RI 2009). Untuk itu perlu dibedakan antara hewan peliharaan yang dikenal dengan companion animal dengan ternak. Meskipun keduanya adalah hewan peliharaan, namun tujuan pemeliharaan keduanya adalah berbeda, sehingga terdapat perbedaan dalam aspek-aspek pemeliharaannya.

Hewan peliharaan merupakan suatu objek beban tambahan bagi manusia. Beban yang dimaksudkan adalah beban secara materi, moril, dan waktu. Beban materi berupa biaya tambahan untuk pakan, minum, kandang, kesehatan, dan kebutuhan lainnya. Bahkan menurut Wolf et al., (2008), muncul satu kebiasaan yang terjadi di Amerika Serikat berupa pemilik hewan peliharaan bersedia menghabiskan banyak uang mereka untuk kesehatan hewan peliharaannya. Beban moril berupa perhatian dan kasih sayang dari pemilik untuk hewan yang dipeliharanya karena hewan mampu memproses kognitif dan perasaan (Knight dan Barnett 2008). Beban waktu berupa sejumlah waktu yang harus diluangkan pemilik untuk memandikan, mengajak bermain atau berjalan-jalan, dan konsultasi kesehatan.

Memelihara hewan bukan hanya sekedar memelihara layaknya hewan ternak, pemilik hewan juga harus memerhatikan yang disebut dengan kesejahteraan hewan (animal welfare). Banyak hal yang harus dipenuhi oleh pemilik hewan untuk menjamin hewan peliharaannya sejahtera. Memelihara hewan diikuti dengan adanya tuntutan berupa kewajiban untuk bertanggung jawab terhadap keberlangsungan hidup hewan peliharaannya. Bahkan pemilik hewan peliharaan harus memperlakukan hewannya dengan manusiawi (Bogdanoski 2010). Tidak hanya memastikan bahwa hewan peliharaannya dapat hidup, tetapi juga pemilik harus mampu memastikan hewan peliharaannya dalam kondisi sehat secara fisik dan mental serta tidak kekurangan suatu apapun, seperti pakan, minuman dan tempat berteduh. Memelihara companion animal dapat dijadikan sebagai sarana rekreasi dengan cara bermain bersama hewan peliharaan, mengisi waktu luang dengan memandikan atau mengajak berjalan-jalan hewan peliharaan.

Menurut Maroef (1989), bahwa 46,6\% dari 1600 keluarga di DKI Jakarta memiliki hewan peliharaan. Imbas dari perkembangan zaman dan gaya hidup, diperkirakan jumlah ini akan terus meningkat. Dengan semakin, meningkatnya tuntutan penerapan kesejahteraan hewan, maka dirasa perlu dilakukan suatu studi untuk mengetahui dan mengevaluasi penerapan kesejateraan hewan oleh pemilik hewan peliharaan.

Penelitian ini bertujuan untuk mendapatkan gambaran mengenai hubungan tingkat pendidikan dan status ekonomi pemilik hewan peliharaan dengan pengetahuan dan penerapan asas kesejahteraan hewan (animal welfare).

\section{METODE PENELITIAN}

Data dalam penelitian ini diperoleh melalui kuisioner yang diisi oleh pemilik hewan pada saat datang ke Rumah Sakit Hewan Jakarta di Jakarta Selatan, ZEN Pet Clinic di Jakarta Utara, Praktek Dokter Hewan drh Mona di Jakarta Barat, ZEN Veterinary Shop Gajah Mada Plaza di Jakarta Pusat.

\section{Rancangan Penelitian}

Jumlah responden dalam penelitian ini adalah 50 responden untuk setiap lokasi. Menurut Lindner et al., (2001), jumlah minimal responden yang diperlukan untuk penelitian sejenis adalah 30 responden.

\section{Jenis dan Cara Pengumpulan Data}

Perangkat yang digunakan dalam peneliltian ini adalah kuisioner yang disusun untuk memperoleh data. Cara perolehan data dengan kuisioner dilakukan dengan cara wawancara tatap muka atau teknik face to face interview bagi pengunjung di lokasi penelitian. Interview merupakan teknik yang digunakan untuk mengetahui persepsi dan perilaku (Driscoll, 2011)

\section{Rancangan kuisioner}

Kuisioner terdiri dari dua bagian yang tersusun atas 34 pertanyaan. Bagian pertama menjaring data responden dan bagian kedua menjaring data mengenai hubungan responden dengan pola pemeliharaan hewan peliharaan. Pertanyaan mengenai data responden terdiri dari sembilan pertanyaan berupa pertanyaan 
tipe terbuka dan tertutup. Pertanyaan terbuka untuk menanyakan data responden yang membebaskan kepada responden untuk menjawab apa saja. Pertanyaan yang tertutup merupakan pertanyaan yang jawabannya telah disediakan sehingga responden hanya memilih jawaban dari pilihan jawaban yang disediakan. Bagian kedua kuisioner terdiri dari 25 pertanyaan yang berisi pertanyaan mengenai pengetahuan dan penerapan tentang aspek kesejahteraan hewan terhadap hewan peliharaan responden. Dari 25 pertanyaan tersebut, pertanyaan-pertanyaan tersebut dibagi lagi menjadi tiga bagian besar pertanyaan, yaitu sepuluh pertanyaan yang menanyakan tentang aspek pengetahuan responden, delapan pertanyaan tentang aspek perilaku responden dan tujuh pertanyaan tentang sikap responden. Pertanyaan pada bagian kedua ini diberikan pilihan jawaban setuju, kurang setuju, dan tidak setuju.

Penyusunan daftar pertanyaan ini mengacu pada Fauzi (2006) yang meneliti mengenai kesejahteraan orangutan dan beberapa sumber lain yang melakukan studi mengenai hubungan antara pemilik dengan hewan peliharaannya (Carlisle-Frank dan Frank, 2006; Keenan, 2010; Lue et al., 2007; Rehn, 2013) yang kemudian disesuaikan dengan penelitian dengan fokus pada kesejahteraan hewan serta studi mengenai pengetahuan dan perilaku.

Pengukuran Pengetahuan. Pengukuran pengetahuan dilakukan dengan menggunakan sepuluh pertanyaan dengan pilihan jawaban setuju, kurang setuju, dan tidak setuju. Jawaban setuju, kurang setuju, dan tidak setuju masing-masing diberi nilai 1 . Jika responden menjawab delapan atau lebih pertanyaan dengan jawaban setuju maka responden dikelompokkan sebagai responden berpengetahuan tinggi.

Pengukuran Sikap. Pengukuran sikap dilakukan dengan menggunakan tujuh pertanyaan dengan pilihan jawaban setuju, kurang setuju, dan tidak setuju. Jawaban setuju, kurang setuju, dan tidak setuju masingmasing diberi nilai 1. Jika responden menjawab lima pertanyaan atau lebih dengan jawaban setuju maka responden dikelompokkan sebagai responden bersikap baik.

Pengukuran Praktik. Pengukuran praktik dilakukan dengan menggunakan delapan pertanyaan dengan pilihan jawaban setuju, kurang setuju, dan tidak setuju. Jawaban setuju, kurang setuju, dan tidak setuju masing- masing diberi nilai 1. Jika responden menjawab enam pertanyaan atau lebih dengan jawaban setuju maka responden dikelompokkan sebagai responden yang melaksanakan dengan baik.

Tingkat pendidikan rendah dinyatakan bagi responden dengan pendidikan terakhir adalah SD dan SMP, atau yang sederajat. Tingkat pendidikan menengah dinyatakan bagi responden dengan pendidikan terakhir SMA atau yang sederajat. Tingkat pendidikan tinggi dinyatakan bagi responden dengan pendidikan terakhir diploma I (DI), atau lebih tinggi (Kemendikbud 2012).

Data tingkat pendidikan responden didapatkan dari pertanyaan tunggal. Sedangkan untuk pengetahuan responden tentang asas kesejahteraan hewan didasarkan pada frekuensi jawaban setuju dari pertanyaan-pertanyaan yang digunakan untuk menjadi indikator tingkat pengetahuan responden tentang asas kesejahteraan hewan.

Tingkat ekonomi rendah dinyatakan (dalam rupiah) bagi responden dengan pengeluaran pembayaran listrik kurang dari 500.000 dan pengeluaran untuk pembelanjaan kebutuhan hewannya kurang dari 100.000. Tingkat ekonomi menengah dinyatakan bagi responden dengan pengeluaran pembayaran listrik 500.000-1.000.000 dan pengeluaan untuk kebutuhan hewannya 100.000-500.000. Tingkat ekonomi tinggi dinyatakan bagi responden dengan pengeluaran pembayaran listrik 1.000.000-3.000.000 atau lebih dari 3.000.000 serta pengeluaran untuk kebutuhan hewannya 500.000-1.000.000 atau lebih dari 1.000.000.

Data mengenai status ekonomi responden didapatkan melalui pertanyaan dalam kuisioner. Pertanyaan tidak mengarah langsung terhadap pendapatan, melainkan diarahkan pada besarnya pengeluaran untuk pembayaran listrik rumah per bulan, jenis atau jumlah perleng-kapan alat elekronik di rumah serta pertanyaan mengenai pengeluaran untuk hewan peliharaan. Hal ini dilakukan untuk mendapatkan informasi yang menyeluruh mengenai kemampuan keuangan responden, karena yang menjadi responden bisa saja pemilik hewan peliharaan, perawat hewan atau penjaga rumah.

\section{Analisis Data}

Data yang diperoleh dari hasil pengisian kuisioner dibuat pembobotan (scoring). Data tersebut kemudian diolah secara deskriptif dan dengan uji chi square. 
Analisis deskriptif digunakan untuk membuat gambaran secara sistematis, faktual dan akurat mengenai fakta-fakta, sifat-sifat serta hubungan antar fenomena yang diselidiki. Uji chi square digunakan untuk data kualitatif dan menguji hubungan antara dua variabel yang tidak berkaitan (Heiman 2011). Perhitungan chi square dilakukan dengan program SPSS $16^{\mathrm{TM}}$ dan Microsoft Excel 2007 ${ }^{\mathrm{TM}}$.

Perhitungan chi square dilakukan menggunakan rumus berikut ini

$X^{2}$ hitung $=\frac{\sum(|o b s-e x p|)^{2}}{\exp }$

untuk

obs : nilai observasi atau nilai yang ada pada data

exp : nilai expektasi atau notasi untuk nilai harapan, yang didapatkan dari (hasil kali total kolom dengan total baris) dibagi total data

\section{HASIL DAN PEMBAHASAN}

Penyebaran Tingkat Pendidikan dan Ekonomi Responden Berdasarkan Lokasi

Tingkat pendidikan dari responden dapat digambarkan dari jawaban responden pada kuisioner yang disajikan dalam Tabel 1.
Sebagian besar responden di Jakarta Selatan berlatar belakang pendidikan tinggi. Latar belakang pendidikan yang seperti ini sangat membantu ketika dilakukan wawancara secara langsung. Jawaban-jawaban dapat dengan mudah diperoleh dan jawaban tersebut sudah mencerminkan karakter pendidikan responden.

Gambaran penyebaran tingkat pendidikan responden di Jakarta Utara dan Jakarta Pusat adalah serupa. Hal ini sesuai dengan data Badan Pusat Statistik/BPS Provinsi DKI Jakarta (2013) yang menyajikan bahwa persentase rataan lama sekolah di kedua wilayah tersebut tidak berbeda nyata, yaitu 10,77\% untuk Jakarta Pusat dan 10,07\% untuk Jakarta Utara. Namun, kedekatan nilai penyebaran tingkat pendidikan di kedua wilayah ini tidak terjadi pada penyebaran tingkat ekonominya. Jakarta Utara memiliki persentase tingkat ekonomi yang tinggi, yaitu $64 \%$, yang berbeda jauh dengan Jakarta Pusat yang hanya 24\% (Tabel 2).

Responden yang berada di wilayah Jakarta Utara, Jakarta Selatan, dan Jakarta Barat merupakan responden dengan status ekonomi tinggi. Responden dengan tingkat ekonomi tinggi paling banyak berada di wilayah Jakarta Selatan.

Tabel 1. Penyebaran tingkat pendidikan responden berdasarkan lokasi

\begin{tabular}{|c|c|c|c|c|c|c|c|c|}
\hline \multirow{3}{*}{$\begin{array}{c}\text { No } \\
1 .\end{array}$} & \multirow{3}{*}{$\begin{array}{l}\text { Lokasi } \\
\text { Jakarta Utara }\end{array}$} & \multicolumn{6}{|c|}{ Tingkat pendidikan } & \multirow{3}{*}{$\begin{array}{c}\begin{array}{c}\text { Jumlah } \\
\text { responden }\end{array} \\
50\end{array}$} \\
\hline & & \multicolumn{2}{|c|}{ Rendah } & \multicolumn{2}{|c|}{ Menengah } & \multicolumn{2}{|c|}{ Tinggi } & \\
\hline & & 5 & $(10 \%)$ & 13 & $(26 \%)$ & 32 & $(64 \%)$ & \\
\hline 2. & Jakarta Selatan & 1 & $(2 \%)$ & 8 & $(16 \%)$ & 41 & $(82 \%)$ & 50 \\
\hline 3. & Jakarta Barat & 4 & $(8 \%)$ & 9 & $(18 \%)$ & 37 & $(74 \%)$ & 50 \\
\hline \multirow[t]{2}{*}{4.} & Jakarta Pusat & 4 & $(8 \%)$ & 13 & $(26 \%)$ & 33 & $(66 \%)$ & 50 \\
\hline & Total & 14 & $(7 \%)$ & 43 & $(22 \%)$ & 143 & $(71 \%)$ & 200 \\
\hline
\end{tabular}

Tabel 2. Penyebaran tingkat ekonomi responden berdasarkan lokasi

\begin{tabular}{lllllllll}
\hline \multirow{2}{*}{ No. } & Lokasi & \multicolumn{8}{c}{ Tingkat Ekonomi } & \multirow{2}{*}{ Jumlah } \\
\cline { 3 - 7 } & & \multicolumn{2}{c}{ Tinggi } & \multicolumn{2}{c}{ Menengah } & \multicolumn{2}{c}{ Rendah } & \\
\hline 1. & Jakarta Utara & 32 & $(64 \%)$ & 16 & $(32 \%)$ & 2 & $(4 \%)$ & 50 \\
2. & Jakarta Selatan & 37 & $(74 \%)$ & 13 & $(26 \%)$ & 0 & $(0 \%)$ & 50 \\
3. & Jakarta Barat & 35 & $(70 \%)$ & 11 & $(22 \%)$ & 4 & $(8 \%)$ & 50 \\
4. & Jakarta Pusat & 12 & $(24 \%)$ & 34 & $(68 \%)$ & 4 & $(8 \%)$ & 50 \\
& & 116 & $(58 \%)$ & 74 & $(37 \%)$ & 10 & $(5 \%)$ & 200 \\
\hline
\end{tabular}


Tabel 3. Penyebaran tingkat ekonomi menurut pendidikan responden

\begin{tabular}{llllll}
\hline \multirow{2}{*}{ Ekonomi } & \multicolumn{5}{c}{ Pendidikan } \\
\cline { 2 - 4 } & Tinggi & Menengah & Rendah & Jumlah & $p_{\text {value }}$ \\
\hline Tinggi & 85 & 21 & 10 & 116 & 0,450 \\
Menengah & 51 & 20 & 3 & 74 & \\
Rendah & 7 & 2 & 1 & 10 & \\
Total & 143 & 43 & 14 & 200 & \\
\hline
\end{tabular}

Setelah dilakukan perhitungan terhadap data yang ada pada Tabel 1 dan Tabel 2, didapatkan hasil bahwa nilai $p$ value adalah $0,450(p>0,05)$ (Tabel 3). Hasil ini menunjukkan bahwa tidak ada hubungan yang bermakna antara tingkat ekonomi dengan pendidikan responden. Pendidikan tinggi belum tentu memiliki status ekonomi tinggi. Begitu pun sebaliknya, pendidikan rendah belum tentu tidak dapat memiliki status ekonomi tinggi.

\section{Hubungan Tingkat Pendidikan dengan Pengetahuan dan Penerapan Asas Kesejahteraan Hewan}

Analisis data parameter pendidikan, pengetahuan, sikap dan perilaku responden terhadap hewan peliharaan mereka disajikan pada Tabel 4.

Tabel 4. Hubungan antara pendidikan dengan pengetahuan, sikap, dan perilaku terhadap asas kesejahteraan hewan

\begin{tabular}{|c|c|c|c|}
\hline \multirow{2}{*}{ Parameter } & \multicolumn{3}{|c|}{ Pendidikan } \\
\hline & Pengetahuan & Sikap & Perilaku \\
\hline Jakarta Utara & 1,000 & 0,680 & 0,940 \\
\hline Jakarta Selatan & 1,000 & $0,000 *$ & 1,000 \\
\hline Jakarta Barat & 0,7000 & 0,700 & 0,460 \\
\hline Jakarta Pusat & 0,320 & 0,060 & 0,480 \\
\hline
\end{tabular}

*p value dengan nilai beda nyata $(<0,05)$

Sikap responden di Jakarta Selatan terhadap hewan peliharaannya dipengaruhi oleh tingkat pendidikan responden ( $p$ value $=0,000$ $p<0,05)$. Hasil ini menunjukkan bahwa terdapat hubungan yang bermakna antara tingkat pendidikan responden Jakarta Selatan dengan sikap mereka terhadap asas kesejahteraan hewan.
Berdasarkan kelima asas kesejahteraan hewan yang dikemukakan FAWC (1993) yaitu; (i) bebas dari rasa haus, rasa lapar dan kekurangan gizi dengan menyediakan air dan diet untuk menjaga kesehatan dan menjaga agar hewan tetap memiliki kekuatan; (ii) bebas dari ketidaknyamanan dengan menyediakan lingkungan yang sesuai, termasuk tempat tinggal dan daerah yang nyaman; (iii) bebas untuk beristirahat dan bebas dari rasa nyeri, cedera dan penyakit dengan pencegahan atau tindakan sigap untuk mendiagnosis dan melakukan pengobatan; (iv) bebas dari rasa takut dan kesusahan dengan memastikan kondisi yang terhindar penderitaan mental; dan (v) bebas untuk menampilkan perilaku normal dengan menyediakan ruang yang cukup, fasilitas yang tepat dan sesuai dengan jenis hewan itu sendiri responden Jakarta Selatan menunjukkan perbedaan sikap dengan responden di lokasi lainnya yaitu terhadap dua asas saja, yaitu asas bebas dari rasa nyeri dan asas bebas untuk mengekspresikan perilaku alami. Sikap terhadap asas bebas dari rasa nyeri ditunjukkan dengan adanya aksi atau tindakan responden untuk membawa hewan peliharaannya ke Rumah Sakit Hewan Jakarta. Dalam hal ini, RSH Jakarta sebagai lokasi penelitian. Responden menyadari bahwa rasa nyeri yang dialami oleh hewan peliharaannya harus segera dihilangkan. Sikap terhadap asas bebas untuk mengekspresikan perilaku alami tidak menunjukkan hubungan yang positif. Penilaian terhadap asas ini dilakukan dengan mengetahui persepsi responden terhadap perkawinan hewan peliharaannya. Beberapa responden Jakarta Selatan memiliki hewan peliharaan dalam jumlah yang besar. Alasan responden memelihara hewan tersebut adalah sebagai wujud peduli dengan hewan-hewan yang terlantar akibat tingginya populasi, terutama kucing. Sebagai upaya untuk mencegah 
Tabel 5 Penyebaran pengetahuan responden berdasarkan lokasi

\begin{tabular}{lllll}
\hline \multirow{2}{*}{ No. } & Lokasi & \multicolumn{2}{c}{ Pengetahuan } & Jumlah \\
\cline { 3 - 4 } & & Tinggi & Rendah & \\
\hline 1. & Jakarta Utara & $28(56 \%)$ & $22(44 \%)$ & 50 \\
2. & Jakarta Selatan & $24(48 \%)$ & $26(52 \%)$ & 50 \\
3. & Jakarta Barat & $26(52 \%)$ & $24(48 \%)$ & 50 \\
4. & Jakarta Pusat & $25(50 \%)$ & $25(50 \%)$ & 50 \\
& Total & 103 & 97 & 200 \\
\hline
\end{tabular}

peningkatan populasi dan meningkatnya jumlah hewan yang terlantar, maka beberapa responden memilih untuk melakukan sterilisasi hewan peliharaan. Satu sisi tindakan ini melanggar asas bebas mengekspresikan perilaku alami, namun di sisi lain tindakan ini mendukung terciptanya asas bebas dari rasa lapar dan haus.

Tingkat pendidikan dengan aspek pengetahuan dan perilaku responden di semua lokasi penelitian menunjukkan nilai $p$ value yang lebih besar dari 0,05 , artinya tidak berbeda nyata. Tingkat pendidikan tidak memiliki hubungan bermakna dengan pengetahuan dan perilaku terhadap asas kesejahteraan hewan. Tingginya tingkat pendidikan yang ditempuh oleh responden tidak menjamin bahwa responden memiliki pengetahuan yang baik akan asas kesejahteraan hewan. Kepentingan penerapan asas ini pun tidak dapat dipahami dengan baik oleh responden karena dalam pendidikan yang ada di Indonesia memang belum menerapkan tentang ajaran mengenai cara memperlakukan sesama makhluk hidup terutama hewan. Dalam sebuah studi dilaporkan hasil bahwa terdapat hubungan yang berbanding terbalik antara tingkat pendidikan dengan menjaga hewan peliharaan. Dengan tingkat pendidikan yang tinggi, proporsi menjaga hewan peliharaan rendah (White 2009).

Berdasarkan informasi dan pengamatan yang berlangsung selama penelitian didapatkan gambaran bahwa responden di Jakarta Utara menganggap hewan peliharaan sebagai teman dan anggota keluarga. Pandangan dan sikap seperti ini menimbulkan perhatian yang sangat besar terhadap hewan peliharaannya tersebut. Perbedaan tujuan pemeliharaan hewan atau penggunaan hewan peliharaan berpengaruh terhadap tingkat empati pemilik hewan peliharaan terhadap hewan peliharaannya (Ellingsen et al, 2010). Responden di wilayah Jakarta Utara juga cenderung lebih sering membawa hewan peliharaannya ke klinik hewan atau dokter hewan. Hal ini karena kepedulian dan perhatian mereka yang tinggi terhadap hak-hak dasar hewan peliharaan yang mereka miliki. Kepedulian dan perhatian yang tinggi memicu keinginan pemilik untuk lebih memahami bagaimana cara agar hewan peliharaan mereka sejahtera. Terbukti dengan responden Jakarta Utara memiliki persentase pengetahuan tertinggi dibandingkan dengan lokasi lain seperti disajikan Tabel 5 .

Hasil yang berbeda terlihat pada pengetahuan responden di wilayah Jakarta Selatan. Dari hasil diskusi dan pengisian kuisioner yang dilakukan memperlihatkan bahwa pengetahuan responden mengenai kesejahteraan hewan sangat rendah. Melalui pendalaman hasil diskusi diperoleh satu penilaian bahwa responden memiliki hewan tersebut karena rasa kasihan. Bahkan ada di antara responden yang justru bertindak sebagai penyelamat hewan (animal resque). Dengan latar belakang sikap seperti itu, maka tidak heran bahwa jumlah kepemilikan hewan pelihara responden di wilayah Jakarta Selatan cukup banyak. Secara rataan, seorang responden memiliki lebih dari 10 ekor hewan peliharaan. Mereka hanya memikirkan cara mempertahankan hewan mereka untuk tetap hidup. Masalah penyakit dan cara perawatan tidak begitu mereka pedulikan. Kebanyakan dari responden justru tidak mengandangkan hewan atau menempatkannya di area tertentu. Hewan peliharaan tersebut mereka lepaskan begitu saja. 


\section{Hubungan Status Ekonomi dengan Pengetahuan dan Penerapan Asas Kesejahteraan Hewan}

Analisis data parameter ekonomi, pengetahuan, sikap dan perilaku responden terhadap hewan peliharaan disajikan pada Tabel 6.

Tabel 6. Hubungan antara status ekonomi dengan pengetahuan, sikap, dan perilaku terhadap asas kesejahteraan hewan

\begin{tabular}{llll}
\hline \multirow{2}{*}{ Wilayah } & \multicolumn{3}{c}{ Ekonomi } \\
\cline { 2 - 4 } & Pengetahuan & Sikap & Perilaku \\
\hline Jakarta Utara & 0,300 & 0,320 & $0,040^{*}$ \\
Jakarta Selatan & 0,624 & 0,523 & 0,171 \\
Jakarta Barat & 0,320 & 0,520 & 0,560 \\
Jakarta Pusat & 0,060 & $0,020^{*}$ & 0,140 \\
\hline
\end{tabular}

*p value dengan nilai beda nyata $(<0,05)$

Dari Tabel 6 diperoleh informasi bahwa sikap responden di Jakarta Pusat berhubungan dengan tingkat ekonomi responden, dan tingkat ekonomi responden di Jakarta Utara berhubungan dengan perilaku responden.

Adanya hubungan antara ekonomi dengan sikap responden Jakarta Pusat ditunjukkan oleh persepsi responden terhadap seluruh asas kesejahteraan hewan adalah baik. Sikap merupakan pandangan atau persepsi responden, dalam hal ini adalah terkait dengan asas kesejahteraan hewan. Berdasarkan informasi yang diperoleh saat penelitian, responden Jakarta Pusat menganggap bahwa kesejahteraan hewan memang penting untuk diwujudkan, namun segala aspek perwujudannya disesuaikan dengan anggaran dari pengeluaran responden untuk hewan peliharannya. Anggaran pengeluaran untuk hewan peliharaan juga dipengaruhi oleh kedekatan hubungan antara pemilik hewan dengan hewan peliharaan. Hubungan antara pemilik dengan hewan peliharaan (anjing) dikaitkan dengan beberapa faktor yaitu: (1) kedekatan emosional dengan anjing mereka, 2) terlibat dalam kegiatan dengan anjing mereka, dan 3) adanya biaya yang harus dikeluarkan berkaitan dengan kepemilikan anjing (Dwyer et al., 2006)

Responden Jakarta Utara menganggap hewan peliharaan sebagai teman atau bahkan anggota keluarga. Sikap loyal pemilik terhadap hewan peliharaan menyebabkan pengeluaran mereka untuk kebutuhan hewan peliharaan lebih besar dibandingkan responden dari wilayah lain. Dari perilaku tersebut dapat dilihat bahwa responden Jakarta Utara akan melakukan apapun untuk menjamin kesejahteraan hewan peliharaannya. Mereka menjamin kecukupan jumlah dan nilai gizi dari pakan yang diberikan sehingga sesuai dengan kebutuhan fisiologi hewan. Responden tidak menginginkan hewannya sakit dan kalaupun mengalami sakit, mereka akan segera membawanya ke dokter hewan, klinik hewan, atau rumah sakit hewan. Sebagian responden Jakarta Utara tidak pernah melewatkan jadwal vaksinasi untuk hewan peliharannya. Beberapa responden juga lebih mempercayai klinik hewan atau layanan kesehatan hewan yang juga melayani grooming untuk merawat penampilan hewan peliharaannya. Hal ini dilakukan sebagai wujud dari perilaku kecintaan mereka terhadap hewan peliharannya. Penghargaan pemilik terhadap hewan peliharaan dapat berwujud pada penjagaan, penempatan yang baik, serta pemahaman terhadap rasa nyeri dan penderitaan (Milligan 2009). Hal ini pula yang menjadi dasar bahwa untuk menyikapi asas-asas kesejahteraan hewan diperlukan pengeluaran yang tidak sedikit (Garner, 2010). Responden sangat mendukung sikap agar hewan dapat memperlihatkan ekspresi fisiologinya. Perilaku ini diperlihatkan dengan kesediaan responden mengeluarkan biaya tambahan untuk mengawinkan dan membiayai persalinan hewan peliharannya.

Berbeda halnya dengan responden Jakarta Selatan yang lebih menginginkan hewan peliharaannya tidak bertambah banyak dengan memilih tindakan kebiri/kastrasi atau ovariohisterektomi $(\mathrm{OH})$.

Dengan adanya hasil ini, maka dapat dikatakan bahwa kemampuan keuangan yang tinggi berakibat pada perilaku atau tindakan responden terhadap hewan peliharaannya. Dengan kemampuan keuangan yang tinggi, responden dapat memenuhi segala kebutuhan hewan peliharaannya. Kebutuhan tersebut dapat saja dalam bentuk penyediaan pakan yang sesuai dengan kondisi hewan peliharaan (sakit, jenis hewan, sedang bunting, pada status anakan dan lainnya). Selain itu juga mampu membiayai segala program kesehatan, seperti pemberian vaksinasi dan pemberian obat cacing, untuk hewan peliharaannya. Bahkan menurut 
Bennett et al., (2007) pemilik juga rela mengeluarkan sejumlah dana untuk melatih kedisiplinan hewan peliharaannya.

\section{Perbedaan Persepsi Responden}

Berdasarkan hasil wawancara dengan responden yang merupakan pengunjung toko hewan peliharaan (pet shop) dan responden yang mendatangi klinik, dokter hewan dan rumah sakit, penelitian ini mendapatkan garis besar pandangan mereka tentang hewan peliharaan. Sebagian besar memang mendatangi toko hewan peliharaan untuk membeli pakan hewan atau sekadar membeli aksesoris. Mereka mendatangi toko hewan peliharaan tanpa harus membawa serta hewan peliharaan. Secara umum, pengunjung yang mendatangi toko hewan peliharaan tersebut adalah para calon pemilik hewan atau responden yang ingin membeli hewan peliharaan baru. Kebanyakan yang datang adalah anak- anak. Mereka pun tidak begitu memahami tentang aspek-aspek kesejahteraan hewan. Hasil ini serupa dengan satu survei yang pernah dilakukan pada pengunjung di salah satu toko hewan peliharaan terbesar di Jakarta, yaitu Gajah Mada Plaza. Masyarakat mendatangi toko hewan peliharaan dengan tujuan melihat-lihat (42\%), mencari hewan peliharaan (32\%), dan membeli pakan hewan (16\%) (ZPC, 2010).

Berdasarkan penelitian tersebut, didapatkan pula satu informasi yang menarik dari responden-responden yang datang ke area toko hewan peliharaan, yaitu mereka tidak memahami tindakan-tindakan ilegal yang mereka terima. Misalnya, ketika akan melakukan tindakan pencegahan penyakit melalui program vaksinasi, mereka mendatangi toko hewan peliharaan untuk mendapatkan vaksinasi tersebut yang ternyata dilakukan oleh seseorang yang bukan dokter hewan.

Dibandingkan dengan responden yang datang ke klinik, dokter hewan atau rumah sakit, responden yang mendatangi toko hewan peliharaan lebih mengutamakan hewan peliharaan dalam hal tampilan dan lebih suka pada jenis anakan. Begitu dewasa, beberapa di antara mereka justru menganggap hewan peliharaan sebagai beban yang menyusahkan.

\section{SIMPULAN}

Terdapat hubungan yang saling memengaruhi antara tingkat pendidikan dan status ekonomi dengan penerapan kesejahteraan hewan. Tingkat pendidikan responden Jakarta Selatan memengaruhi sikap terhadap asas kesejahteraan hewan. Status ekonomi responden Jakarta Pusat memengaruhi sikap terhadap asas kesejahteraan hewan, dan status ekonomi responden Jakarta Utara memengaruhi perilaku terhadap asas kesejahteraan hewan. Tidak ada responden yang menunjukkan hubungan yang saling memengaruhi antara tingkat pendidikan dan status ekonomi dengan pengetahuan terhadap kesejahteran hewan.

\section{SARAN}

Berdasarkan hasil penelitian, maka penulis menyarankan perlu diadakannya survei dengan responden masyarakat umum, baik yang memiliki hewan peliharaan maupun tidak. Hal ini bertujuan untuk melihat pandangan masyarakat umum tentang kesejahteraan hewan. Selain itu, penulis menyarankan untuk melakukan penelitian dengan responden adalah pemilik hewan dengan berbagai tingkat pendidikan (SD, SMP, SMA). Hal ini bertujuan untuk melihat tingkat pendidikan yang tepat untuk penanaman pemahaman tentang kesejahteraan hewan.

\section{UCAPAN TERIMA KASIH}

Peneliti mengucapkan terima kasih yang sebesar-besarnya kepada Direktur Rumah Sakit Hewan Jakarta di Jakarta Selatan, drh. Dodi Iwan Suparno selaku Manajer Klinik ZEN Pet Clinic di Jakarta Utara dan ZEN Veterinary Shop Gajah Mada Plaza di Jakarta Pusat, dan drh. Mona selaku pemilik Praktek Dokter Hewan drh. Mona di Jakarta Barat.

\section{DAFTAR PUSTAKA}

Bennett PC, Cooper N, Rohlf V, Mornement K. 2007. Factor influencing owner satisfaction with companion dog training facilities. $J$ App Anim Welfare Sci 10(3) : 217-241.

Bogdanoski T. 2010. Toward an animals friendly family law: Recognising the welfare of family law's forgotten family members. Griffith Law Rev 19(2) : 197-237. 
[BPS] Badan Pusat Statistik. 2013. Indeks pembangunan manusia Provinsi DKI Jakarta tahun 2011 [Internet]. [diunduh 20 Maret 2013]. Tersedia pada: http:// jakarta.bps.go.id

Carlisle-Frank P, Frank JM. 2006. Owners, guardians, and owner-guardians: differing relationships with pets. Anthrozoos 19(3) : 225-242

Driscoll DL. 2011. Introduction to Primary Research: Observations, Surveys, and Interviews. In: Writing Spaces: Readings on Writing. $2^{\text {nd }}$ ed. West Lafayette (US): Parlor Press

Dwyer F, Bennett PC, Coleman GC. 2006. Development of the Monash Dog Owner Relationship Scale (MDORS). Anthrozoos 19(3) : 243-256.

Ellingsen K, Zanella AJ, Bjerkas E, Indrebo A. 2010. The relationship between empathy, perception of pain and attitudes toward pets among Norwegian dog owners. Anthrozoos 23(3) : 231-243.

[FAWC] Farm Animal Welfare Council. 1993. Second report on priorities for research and development in farm animal welfare. United Kingdom: MAFF Tolworth

Fauzi RPS. 2006. Medis konservasi berbasis kesejahteraan hewan: Studi kasus pada orangutan di Taman Marga Satwa Ragunan. Bogor. Fakultas Kedokteran Hewan. Institut Pertanian Bogor.

Garner R. 2010. Animals, ethics and public policy. Polit Quart 81(1) : 123-130.

Heiman GW. 2011. Basic Statistics for the Behavioral Sciences. $6^{\text {nd }}$ ed. Belmont: Wadsworth. Pp 351

Keenan TA. 2010. Pet ownership and excercise. AARP Bul Poll Pp: 1-6

[Kemendikbud] Kementerian Pendidikan dan Kebudayaan RI. 2012. Revisi Rencana
Strategis Direktorat Jenderal Pendidikan Menengah 2010-2014. Jakarta: Kementerian Pendidikan dan Kebudyaan Republik Indonesia.

Knight S, Barnett L. 2008. Justifying attitudes toward animal use: a qualitative study of people's views and beliefs. Anthrozoos 21: 31-42.

Lindner JR, Murphy TH, Briers GE. 2001. Handling nonresponse in social science. $J$ Agric Education 42(4) : 43-53.

Lue T, Pantenburg D, Crawford P. 2007. Perceptions and attitudes of pet owners: the impact of the bond. BNResearch Pp 1-38

Maroef S. 1989. Kepadatan populasi anjing sebagai penular rabies di DKI Jakarta, Bekasi, dan Karawang 1986. Buletin Penelitian Kesehatan 17(1) : 44-48.

Milligan T. 2009. Dependent companions. J App Philosophy 26(4) : 402-413.

Pemerintah Republik Indonesia. 2009. UndangUndang Republik Indonesia Nomor 18 Tahun 2009 tentang Peternakan dan Kesehatan Hewan. Jakarta: Sekretariat Negara

Rehn T. 2013. Best friends? Investigating the dog-human relationship [thesis]. Faculty of Veterinary Medicine: Swedish University of Agricultural Sciences

White S. 2009. Companion Animals: Members of the family or legally discarded objects?. UNSW Law J 32(2) : 852-878.

Wolf C, Lloyd J, Black J. 2008. An examination of US consumer pet-related and veterinary service expenditures, 1980-2005. JAVMA 233 : 404-413.

[ZPC] Zen Pet Clinic. 2010. Consumers Insight para Pengunjung di Lokasi Pet Shop Gadjah Mada Plaza Jakarta Pusat. [Hasil penelitian tidak dipublikasikan] 